Mikayla Hunter*

\title{
Memory, Gender and Recognition in Le Morte Darthur
}

https://doi.org/10.1515/jias-2018-0002

\begin{abstract}
This article examines recognition motifs in earlier English romances to better understand female perception and the use of recognition tokens in Le Morte Darthur. Drawing on the work of Mary Carruthers and Elisabeth van Houts on medieval concepts of memory and emotion and Anne Lester on women's association with the care and keeping of relics, as well as the social and legal roles of women preserving knowledge of familial and sexual relationships, this article argues that medieval English understanding of disguise-perception was gendered and that in medieval culture women were considered to be better at recognising individuals than men. The use of recognition tokens in Middle English romance reflects this gendered view of perception; recognition scenes in Le Morte Darthur uphold this view. In addition, the materiality and efficacy of the recognition tokens in romance denotes the nature of the relationship between the perceiver and the disguised or transformed individual. Thus, when Malory introduces a recognition-token exchange scene between Isolde and Tristan and then frustrates their later recollections and recognitions of each other, he infuses Tristan and Isolde's relationship with a sense of unease that foreshadows their tragic end.
\end{abstract}

Résumé: Cet article analyse les thèmes de reconnaissance dans les romans d'amours anglais médievaux afin de mieux comprendre la perception féminine et l'utilisation de témoignages de reconnaissance dans Le Morte Darthur. S'appuyant sur le travail de Mary Carruthers et d'Elisabeth van Houts sur les concepts médiévaux de la mémoire et de l'émotion, et d'Anne Lester sur le rapport des femmes avec le soin et la conservation des reliques, ainsi que les rôles sociaux et juridiques des femmes qui préservent la connaissance des relations familiales et sexuelles, cet article soutient que la compréhension médiévale anglaise de la perception du déguisement était sexuée et que dans cette même culture les femmes étaient considérées comme étant meilleures à reconnaître les individus que les hommes. L'utilisation de témoignages de reconnaissance dans la romance du Moyen-Age anglais reflète cette vision sexuée de la perception; des scènes de reconnaissance dans Le Morte Darthur soutiennent cette vue. En outre, la maté-

*Corresponding author: Mikayla Hunter, St John's College, University of Oxford, E-Mail: mikayla.hunter@sjc.ox.ac.uk 
rialité et l'efficacité des témoignages de reconnaissance dans la romance dénote la nature de la relation entre l'observateur et l'individu déguisé ou transformé. Ainsi, quand Malory introduit une scène d'échange symbolique entre Isolde et Tristan et entrave ensuite leurs souvenirs et leurs reconnaissances réciproques, il imprègne la relation de Tristan et Isolde d'un sentiment de malaise qui préfigure leur fin tragique.

Zusammenfassung: Dieser Artikel untersucht Erkennungsmotive in frühem englischen Minnegesang, um die weibliche Wahrnehmung und die Verwendung von Erkennungsmarkern in Le Morte Darthur besser zu verstehen. Dieser Artikel argumentiert, in Anlehnung an die Arbeiten von Mary Carruthers und Elisabeth van Houts zu mittelalterlichen Erinnerungs - und Emotionskonzepten und Anne Lester zur Assoziation von Frauenarbeit mit Pflege und Aufbewahrung von Reliquien, sowie der sozialen und rechtlichen Rollen von Frauen, die das Wissen um familiäre und sexuelle Beziehungen bewahren, dass im mittelalterlich-englischen Verständnis Verschleierungswahrnehmung gegendert wahrgenommen wurde; dass nämlich in der mittelalterlichen Kultur davon ausgegangen wurde, dass Frauen erfolgreicher im Durchschauen von Individuen seien als Männer. Die Verwendung von Erkennungsmarkern im mittelenglischen Minnegesang spiegelt diese gegenderte Sichtweise wider; Erkennungsszenen in Le Morte Darthur unterstützen diese Sichtweise. Materialität und Wirksamkeit der Erkennungszeichen im Minnegesang charakterisiert darüber hinaus die Art der Beziehung zwischen dem wahrnehmenden Subjekt und dem verkleideten oder transformierten Individuum. Wenn Malory ebenfalls eine Erkennungs-Zeichen-Austausch-Szene zwischen Isolde und Tristan einführt und dann ihre späteren Erinnerungen aneinander sowie ihre gegenseitige Wiedererkennung ins Leere laufen lässt, verleiht er Tristan und Isoldes Beziehung eine unbehagliche Vorahnung, die ihren tragischen Tod vorwegnimmt.

Keywords: English romance, memory, recognition tokens, Thomas Malory, disguise

In Sir Thomas Malory’s ‘Book of Sir Tristram', Isolde’s mother recognises Tristan by the fragment of sword broken off in his earlier battle with Marhault. Later, Tristan exchanges rings with Isolde, and she promises to remain faithful to him for seven years despite their pending separation - a scene commonly preceding disguise-recognition scenes in other English romances. Throughout the medieval English romances, women are often the first characters to detect a disguise, suggesting a gendered view of perceptiveness - a view to which Malory largely 
adheres. There are three types of narratives in Middle English romances in which the woman is presented with a person in disguise often after a long absence: those in which the woman recognises the person in disguise with the aid of a 'token of recognition' (sections one and two); those in which the woman accurately perceives the identity of the person in disguise without the aid of a visual cue (section three); and those in which the woman is taken in by the disguise (section four).

This article examines recognition motifs in earlier English and English-translation romances, the role of women as witnesses in medieval English legal cases and current scholarship on medieval understandings of memory and recognition to better understand female perception and the use of recognition tokens in Le Morte Darthur. It argues that medieval English understanding of disguise-perception was gendered and that in medieval culture, women were considered to be better at recognising individuals than men. The use of recognition tokens in Middle English romances reflects this gendered view of perception; recognition scenes in Le Morte Darthur uphold this view. The romances this article draws upon to contextualise recognition scenes in Le Morte Darthur include Sir Isumbras, Amis and Amiloun, Lai la Fresne/le Freine, King Horn and Sir Gowther, amongst others. Malory uses contemporary concepts of gendered recognition and well-established romance motifs of disguise recognition throughout the Morte Darthur, and to tragic effect in 'The Book of Sir Tristram'. Failed recognition establishes Igraine's innocence in Arthur's conception; correct recognition illustrates the depth of Elaine of Carbonec's unrequited love for Lancelot and Isolde's mother's grief for Marhault. In addition, the materiality and efficacy of the recognition tokens in each instance denotes the nature of the relationship between the perceiver and the disguised or transformed individual. Thus, when Malory introduces a recognition-token exchange scene between Isolde and Tristan and then frustrates their later recollections and recognitions of each other, he infuses Tristan and Isolde's relationship with a greater sense of unease than is present in Lancelot's similar relationship with Guinevere or in Malory's Prose Tristan source material.

\section{Recognition Tokens}

Contemporary memory culture influenced the shaping of many disguise recognition narratives. The frequent employment of the 'token of recognition' motif in many of these narratives provides some evidence for this. That is, the woman in question does not at first recognise the hero - what Bruce Louden calls 'delayed' 
recognition; eventually an object triggers her recognition, most often a ring exchanged earlier between the lovers. ${ }^{1}$ These recognition tokens operate as what Elisabeth van Houts refers to as 'pegs for memory'. ${ }^{2}$ Memories of people or events were often linked to, or imprinted upon, objects; seeing those objects could then trigger the recollection of the memories with which they were associated. ${ }^{3}$ The frequent presence of these objects in romance recognition scenes points to these women's perspicacity as a matter more of recollection than perception.

In 'The Book of Sir Tristram', Tristan has been masquerading as Tramtryste in the hostile kingdom of Ireland shortly after he has killed the brother of the queen in combat when

The quene behelde his swerde as hit lay uppon his bedde, and than at unhappis the quene drew oute his swerde and behylde hit a longe whyle. And bothe they thought hit a passynge fayre swerde, but within a foote and an halff of the poynte there was a grete pyese thereof outebrokyn of the edge. And whan the quene had aspyed that gappe in the swerde she remembirde hir of a pyese of a swerde that was founde in the brayne-panne of Sir Marhalte that was hir brothir.

'Alas!' than seyde she unto hir doughter La Beale Isode, 'this is the same traytoure knyght that slewe my brothir, thyne eme. ${ }^{4}$

Later, taking his leave of Isolde to return to Cornwall, the audience witnesses another employment of mnemonic objects:

'Madam,' seyde Sir Trystramys, '[...] I promyse you faythfully, I shall be all the dayes of my lyff your knyght.' 'Gramercy,' seyde La Beale Isode, 'and I promyse you thereagaynste I shall nat be maryed this seven yerys but by your assente [...]' And than Sir Trystrames gaff hir a

1 Louden identifies six subtypes: immediate, delayed ('recognition occurs, but later in the same scene'), postponed ('recognition does not occur until a later scene'), reversed ('another character does the testing'), shared (in which 'both characters, protagonist and the other family members, are ignorant of each other's identities'), and that in which 'the protagonist is fully cognizant of other family members' identities when he encounters them, but he refrains from disclosing his own identity, while he tests and probes them'. Bruce Louden 'Is there early recognition between Penelope and Odysseus?: Book 19 in the Larger Context of the Odyssey', College Literature, 38.2 (2011), 76-100 (p. 79).

2 Elisabeth van Houts, Memory and Gender in Medieval Europe, 900-1200 (Basingstoke: MacMillan, 1999), pp. 93-120, particularly p. 93.

3 The 'imprinting' process sometimes involves an element of performativity, combining the giving of the token with words beseeching the recipient to use the object as a memory token (e. g. 'loke her-on \& penk on me'). Amis and Amiloun, ed. by MacEdward Leach, Early English Text Society (Oxford: Oxford University Press, 1937), 1. 323.

4 Sir Thomas Malory, Le Morte Darthur, ed. by P. J. C. Field (Cambridge: D. S. Brewer, 2013), p. 306. 
rynge and she gaff hym another, and therewith he departed fro her, leuynge her makynge grete dole and lamentacion. ${ }^{5}$

These two scenes contain within them the hallmark motifs of token-based disguise-recognition narratives found throughout the English romance tradition, and can be best understood when viewed as late medieval renditions of those earlier motifs and narratives. The sword fragment as recognition token operates in Malory as it does in the Prose Tristan source material and in a manner typical of the recognition-token motif found in other romances popular in England. His adherence to the token-recognition narrative in the early part of 'The Book of Sir Tristram' makes Malory's later frustration of common recognition motifs - with Tristan and Isolde's disrupted ring exchange recognition narrative, discussed below - all the more striking. To best illustrate the impact of Malory's disruption of the recognition narrative between Tristan and Isolde, it is first necessary to examine the recognition motifs in the earlier Middle English romance tradition upon which Malory is building.

The romance of Sir Isumbras provides a good example of the typical use of mnemonic objects often found in romance recognition scenes, and can therefore best illustrate the narrative conventions an audience might have expected when encountering the sword fragment and ring-exchange episodes in Le Morte Darthur. It also demonstrates the endurance of this recognition motif and concept of object-as-mnemonic through the late Middle Ages and into the early modern period. The text was composed prior to 1320 . The surviving manuscripts show a continued rather than revived interest in the text. The earliest of the nine manuscripts dates from the mid-fourteenth century: London, Gray's Inn, MS 20, followed by the late-fourteenth century Oxford, University College, MS 142 to the 1564 transcript in Oxford, Bodleian Library, MS Douce 261. A further six manuscripts were produced throughout the fifteenth century. Moreover, the provenances of these manuscripts range from south-west Sussex up to northern Yorkshire, suggesting a widespread and continuous interest in the text.

A little over a third of the way into the text, the wife of Sir Isumbras, about to be forcibly taken from him by the sultan, slips him a ring as a 'tokene' by which to remember and find her. ${ }^{6}$ Emotional performance accompanies the exchange, with Isumbras's wife making 'grete dole', 'kyssynge' Isumbras and 'clyppynge swete', and beseeching Isumbras: 'in what londe that I am inne, | Fonde the thyder forto

5 Malory, p. 309.

6 In the Cotton manuscript she breaks the ring, each of them keeping a half of it. 
wynne'. She swoons three times. ${ }^{7}$ The sultan then gives Isumbras a bag of gold in exchange for his wife, wrapped in a scarlet mantle. Later, Isumbras encounters his wife whilst he is in the guise of a palmer. In the Cotton manuscript of Sir Isumbras (c. 1446-60), the ring is produced as a mnemonic for Isumbras's wife. Other versions lack the Cotton manuscript's continuity. In this recognition scene the authors conflate the ring with the scarlet mantle filled with gold that the sultan gives to Isumbras when he first parts from his wife. ${ }^{8}$ However, the importance of including a recognition token and the inclusion of a mnemonic performance by the wife remains consistent. The sight of the gold elicits a strong emotional response and triggers her recollection of the hero:

Sone when sche it sawe with syght, In swonyng the lady fell doune ryght, For sche it are hade sene.

Sche kyste it ofte and seyd, 'Alas, This gold owyth Syr Isombras, That my lord was wonte to be.'

As in other female recognition scenes in the romances, this is followed by the hero's affirmation of his identity.

The palmer was brought into the halle.

The quen to counsyll dyd hym calle

And askyd hym, for Godys ore,

If he were ever gentyll man,

And how he that gold wanne.

[...]

With sorowfull hert and syghyng sore,

He gaff hyr an ansuere

And on his kneys hym sette

[...]

Than sche kyssyd his face,

And seyd, 'Welcom, Syr Isombrace!'

For joy thei were wepand. ${ }^{10}$

7 'Sir Isumbras', in Six Middle English Romances, ed. by Maldwyn Mills (London: J. M. Dent and Sons, 1973), pp. 125-47, 11. 325-42.

8 Oxford, Bodleian Library, MS Ashmole 61, fols. 9 ${ }^{\mathrm{r}}-16^{\mathrm{v}}$, 1. 647; from Cambridge, Gonville and Caius College, MS 175: 'Sir Isumbras', in Four Middle English Romances, ed. by Harriet Hudson, TEAMS Middle English Text Society (Kalamazoo: University of Michigan Press, 2006), pp. 11-38, 11. 271-88, 622-51.

9 MS Ashmole 61, 11. 673-78.

10 MS Ashmole 61, 11. 685-702. 
In the multiple recopyings of the manuscript, the presence of $a$ mnemonic object, though not specifically the ring, accompanied by strong emotions both the moment of parting and at the reunion, remain relevant to the reunion narrative. Considering this, it is clear that both the memory imprinted upon the object and the emotionality of the object are essential to her perceptiveness. The same hallmarks of object-triggered recognition appear in the sword-fragment scene of the Morte Darthur: an object that was previously 'given' to the hero (in this case, embedded in his wound) resurfaces when the hero is in disguise. A woman sees the object, recognises it because of an emotionally charged memory she has imprinted upon it, and through this act of memory recollection is able to identify the disguised hero.

Object-driven recognition in the medieval period was strongly gender-associated. Object-triggered recognition is almost exclusively, in English romance, the domain of women (with the exception of Amis and Amiloun, discussed below). Anne Lester has discussed medieval women's association with the care and keeping of relics and the cultivation of the association of those objects with memories of lost male spouses and relatives. She points out how 'crusaders sent relics and reliquaries [...] specifically to their spouses or female kin'; these objects would then 'encode memories' of the absent crusaders. ${ }^{11}$ Often these 'objects were anchored to texts - charters, letters, necrologies and lections - that affirmed the connection between relics and crusaders and that inscribed and informed their continued collective memory'. ${ }^{12}$ Of course, many of these romances were composed as increasing literacy enabled text to encode memory without the need for accompanying objects; such objects were losing much of their relevance in official capacities. However, as Michael Clanchy has found, objects continued to be used occasionally (though not favoured) in oath-taking and proof-of-identity issues at least into the early fourteenth century. ${ }^{13}$ Personal possessions certainly carried - and continue to carry - emotional if not legal relevance; encoding a memory of one's spouse upon, for instance, a wedding ring is more likely and more common than encoding it on the marriage contract.

Almost without exception, the disguised person is someone with whom the woman shares a strong emotional, social, and sometimes sexual, bond - usually

11 Anne E. Lester, 'What Remains: Women, Relics and Remembrance in the Aftermath of the Fourth Crusade', Journal of Medieval History, 40 (2014), 1-18 (pp. 313, 327).

12 Lester, p. 322.

13 Michael Clanchy, From Memory to Written Record (Oxford: Wiley-Blackwell, 2013), pp. 41-43, 256-62. 
the woman's beloved or husband. ${ }^{14}$ This female identification role extends beyond the confines of romance, or even contemporary secular literature. Women, far more than men, were tasked with remembering family and near-kin relations, both in the legal courts and in commemorating those lost to the community. They were entrusted to remember various aspects of personal histories as well - community relationships, social standings, ages or sexual relationships that is, individuals' social identities as much as names and faces. Bronach Kane has discussed the 'social representations of gender [...] prevalent in witness testimony', arguing that a 'fusion of emotional and biological factors produced a gender-based social representation of female memory' that resulted in female witnesses being 'preferred in specific types of suits, indicating that women's memory was valued in certain juridical contexts', specifically 'suits that required memories of births, and proof of sexual activity'. ${ }^{15}$ P. J. P. Goldberg also noted that in marriage and defamation litigation women deponents were 'used in preference to men', particularly in the fourteenth and early-fifteenth centuries - when many of these romances were composed. ${ }^{16}$

Women were also more likely to use objects to aid in memory recall than men. In her examination of a 1365 York trial regarding the legitimacy of Alice de Rouclif's marriage to John Marrays on the grounds that Alice was possibly underage at the time of marriage, Sue Niebrzydowski notes that women were overwhelmingly more likely to reference objects as memory pegs for the event, whereas 'male testimony repeatedly used the Church year as a memorial marker. ${ }^{17}$ In fact, 'only one female witness connected Alice's birth with a national event', whereas other 'testators remembered seeing the cradle in which Alice slept' or other objects present

14 Woman's husband at the time of the disguise or transformation encounter in Middle English romance: Apollonius in Apollonius of Tyre; Isumbras in Sir Isumbras; woman's husband by the end of the text: Havelok in Havelok the Dane; Horn in Horne Childe and Maiden Rimnild and in King Horn; Torrent in Torrent of Portyngale; Uther in Le Morte Darthur and the Prose Merlin; the squire in The Squire of Low Degree; lover: Alexander with Queen Candace in Kyng Alisaunder; Tristan in Sir Tristrem and Le Morte Darthur. In Le Morte Darthur, the women who recognise Tristan and Lancelot still share close social bonds with those men: Elaine loves Lancelot though her affection is unrequited; Isolde's mother hates Tristan as the man who slew her kinsman; Brangwine cares for Tristan as her lady's lover.

15 Bronach Kane, 'Social representations of memory and gender in later medieval England', Integrative Psychological and Behavioral Science, 46.4 (2012), 544-58 (pp. 553, 555, 557).

16 P. J. P. Goldberg, 'Gender and matrimonial litigation in the church courts in the later Middle Ages: The evidence of the court of York', Gender \& History, 19.1 (2007), 43-59 (p. 49).

17 Sue Niebrzydowski, 'From Bedroom to Courtroom: Home and the memory of childbirth in a fourteenth-century marriage dispute', Home Cultures, 6.2 (2009), 123-34 (p.130). 
at the birth such as a 'gift of a prayer script'. ${ }^{18}$ Drawing on Becky R. Lee's work on 'proofs-of-age in Chancery records' that 'even amongst the nobility only 106 out of 1,019 Chancery records mention postpartum purification', Niebrzydowski concludes that 'attendance at one of these [purification] celebrations was more likely to become embedded in a woman's memory' than a man's and finds that 'it is female memory of childbirth that provides the most persuasive evidence' in Rouclif v. Marrays. ${ }^{19}$ From this case study and studies of similar trial records, she concludes that 'in the medieval period, the preservation and transmission of [...] family history as evoked by objects and persons within a household, was, as suggested by Matthew Innes, a role carried out by women' ${ }^{20}$

The gendered association of object-anchored memory and of women as superior witnesses in identity cases is also displayed in the romances when one considers the choice of memory objects in recognition scenes. Van Houts argues that, historically, jewellery and swords in particular were favoured for commemoration of absent or lost husbands and male relatives - the self-same objects which most frequently appear as mnemonic 'pegs' in these romances. ${ }^{21}$ The type of object selected in each romance is usually appropriate to the nature of the relationship between the disguised (or lost/transformed person) and the perceiver. Rings as recognition tokens, for example, appear in Torrent of Portyngale (c. 1400; MS c. $15^{\mathrm{ex}}$ ), King Horn (c. 13 ${ }^{\mathrm{ex}}$; MSS 1300-1340), Horn Childe and Maiden Rimnild (c. 1320; MS c. 1330) and The History of the Holy Grail (c. 1420; MS $15^{\text {th }}$ century) in addition to Sir Isumbras and Le Morte Darthur. They generally denote an erotic relationship between the two characters - a sexual or pseudo-sexual bond as between spouses and lovers, including chaste paramours (discussed more fully below). This is in keeping with some evidence of contemporary uses of rings found outside of romances, such as the illumination of a man giving a ring to a woman in front of a witness in Chantilly, Musée Condé MS 388, a book containing several illuminations of courtly scenes, primarily courtship scenes. Another example is the exchange of a ring love token discussed in a letter from Richard Calle to

18 Niebrzydowski, p.130. Becky R. Lee, 'Men's recollections of a women's [sic] rite: medieval English men's recollections regarding the rite of purification of women after childbirth', Gender and History, 14.2 (2002), pp. 24-42.

19 Niebrzydowski, pp. 130, 125.

20 Niebrzydowski, p. 124; Matthew Innes, 'Keeping it in the Family: Women and Aristocratic Memory, 700-1200', in Medieval Memories: Men, Women and the Past, 700-1300, ed. by Elisabeth van Houts (London: Longman, 2001), pp. 17-35.

21 van Houts, jewellery, pp. 108-9; swords, pp.109-10. These items were valuable; the money invested in them may have contributed to their treasured status. 
Margery Paston in 1469, regarding a man posing as a messenger from Margery, likely employed by those who sought to expose their secret romance:

He [the messenger] told me John Threscher come to hym in your name, and seide that ye sent hym to my ladde for a letter or a token weche I shulde have sent you, but he truste hym not; he wold not delyver hym noon. After that he brought hym a rynge, seyng that ye sent it hym, comaundyng hym that he schulde delyver the letter or token to hym, weche I conceyve sethen be my ladde it was not be your sendyng, it was be my mastres and Sir Jamys a vys. ${ }^{22}$

Rings were likely favoured as mnemonic tokens because they were small, portable, high-value items. Their relative monetary worth also likely made them more valued as keepsakes.

As mentioned above, Marhault's sword fragment in the Tristan cycle operates as a revelatory device. It is similarly appropriate to the nature of the relationship between Iseult's mother and the disguised hero. ${ }^{23}$ Swords, historically and in the romances - especially Arthurian romances - are valuable objects frequently associated with masculine lineage. ${ }^{24}$ The inheritance of a sword from father or other paternal figure to son is a key motif in the Perceval cycle and present in other moments in Arthurian romances, such as Arthur's gift of swords to Gawain and Gueheriet in the Estoire de Merlin. ${ }^{25}$ As Marhault was the queen's brother, a ring closely associated with erotic love - would not be appropriate. As it is through her male family member that the queen and Tristan are connected, a sword is an appropriate 'peg' on which to imprint her memory of the circumstances and people surrounding Marhault's death. Moreover, the queen is shown preserving the sword fragment as the historical women in Lester's research kept memory tokens of their male relatives: in a 'cofyr', much like a reliquary - a detail Malory retains from his French source material. The nature of the object itself evokes a

22 Chantilly, Musée Condé, MS 388, fol. 13', ‘A man giving a ring to a woman’ (vellum, 1475); 'Richard Calle to Margery Paston, 1469', in The Paston Letters, ed. by James Gairdner, 6 vols (London: Chatto and Windus, 1904), V, p. 713.

23 Malory, p. 300; 'Sir Tristrem', in Lancelot of the Laik and Sir Tristrem, ed. by Alan Lupack, TEAMS Middle English Text Society (Kalamazoo: Medieval Institute Publications, 1994), pp. 143277, 11. 1085-98. In Sir Tristrem, Marhalte - here spelt Moraunt - is Iseult's brother.

24 van Houts, pp. 109-10.

25 'L'Estoire de Merlin', in The Vulgate Version of the Arthurian Romances, ed. by H. Oskar Sommer, 8 vols (Washington: Carnegie Institution, 1908-1916), II, p. 422. English translation from 'The Story of Merlin', trans. by Rupert T. Pickens, in Lancelot-Grail, ed. by Norris J. Lacy, 5 vols (London: Routledge, 2010), I, 254. In the Middle English translation, Merlin, or, The early history of King Arthur: a prose romance, ed. by H. B. Wheatley, W. E. Mead, J. Stuart-Glennie and D. W. Nash (London: Early English Text Society, 1865), p. 374. 
relic - 'the pyese of the swerde that was pulde oute of Sir Marhaltys brayne-panne aftir that he was dede' - a fragmentary object connected directly to his death, much like a splinter of the true cross or the piece of St Thomas Becket's skull at Canterbury. ${ }^{26}$

Logan Whalen has discussed the attention paid to 'the interrelationship of memory and mentally visual objects' for audiences of earlier French texts, particularly in the lais of Marie de France. For example, with her hazel twig in Chievrefoil and the tokens she describes as left with the baby Le Fresne in Lai le Fresne, 'one may suppose Marie to have understood that, through carefully assembled descriptions, she could create a type of mentally visual image, an imago or figura, as it were, that would help her as poet retain the materia in the faculty of her memory, and that would also ultimately help those who received her works to "see" the narrative in their own minds and therefore recall its significant moments. ${ }^{27}$ In Chievrefoil, Whalen convincingly argues that Tristan's hazel twig:

has a polyvalent function on two semantic levels. Within the episode itself, Iseut is able to recall the past events that are evoked by the sight of the stick. Likewise, within the broader context of the lai of Chievrefoil, the audience is reminded of the Tristan story in general, as these extradiagetic encounters between Tristan and Iseut are evoked by the latter's previous, similar experiences with the hazel stick. ${ }^{28}$

Whalen also discusses the frequency with which these objects, these tokens, are made 'verbaux' or 'quasi-verbaux' - that is, the objects contain texts as part of their mnemonic value, such as the inscription on the hazel twig or inside the ring left with Le Fresne. ${ }^{29}$ The textile recognition token in Marie de France's Le Fresne and the Middle English translation Lay le Freine both show evidence of the link between the materiality of the token and the relationship it represents in each, but the link between materiality and relationship is made subtly stronger in the English Lay le Freine. ${ }^{30}$ Le Fresne is given up as a baby and raised in a convent unaware of her parentage. Later in life, she is unwittingly present at the wedding of her twin sister (the sisters have never met; La Codre is marrying Le Fresne's

26 Malory, p. 306.

27 Logan E. Whalen, Marie de France and the Poetics of Memory (Washington, D. C.: Catholic University of America Press, 2007), pp. 25-26.

28 Whalen, p. 79.

29 Whalen, pp. 26-27; Rupert T. Pickens, 'Poétique et sexualité chez Marie de France: l'exemple de Fresne', in Et c'est la fin pour quoy sommes ensemble: Hommage à Jean Dufournet, ed. by J.-C. Aubailly et al., 3 vols (Paris: Champion, 1993), III, pp. 1120-21.

30 Indeed, most English romances that incorporate recognition tokens seem to favour 'non-verbaux' tokens to 'verbaux' or 'quasi-verbaux' objects. 
lover) and selflessly lays down the blanket she was once swaddled with on the wedding bed as a gift. Her mother, upon seeing the blanket, 'remembra de li/ Tut li curages li fremi' [remembered her [daughter, Le Fresne] and trembled in her heart']. ${ }^{31}$ This is a transformation rather than a disguise, but the mechanisms of recognition remain the same. As a baby, le Fresne is in fact left with three tokens, two on which Marie focuses and which remain in the Middle English translation: 'And this the mantyll, and this the ring/ You gaf me of yore as a love-tokening'. ${ }^{32}$ The ring seems to have been included due to its popularity as a recognition token specifically associated with 'love', whether between lovers or child and parent, and the inscription upon it is omitted in the English version. However, the author's focus is on the swaddling cloth and it is the cloth alone that actually functions as a recognition token; the ring simply confirms what the cloth has already suggested to Le Fresne's mother. The English translator underscores the greater importance of the blanket: in the English translation, her emotional reaction at seeing the blanket is stronger than in the French: 'whan [...] that mantyll seighe,/ Sche wel neighe swoned oway'. When she awakens, she cries out directly to her daughter in recognition - not to the chamberlain as in the French. ${ }^{33}$ Unlike the gender-neutral ring, a blanket is a feminine object; for women were primarily associated with textile making and embellishment. Moreover, this blanket is a baby blanket, thus invoking the mother-daughter relationship and so is more appropriate than the ring as the mnemonic token in this narrative. ${ }^{34}$

These examples make evident that the objects uses as mnemonic/revelatory devices in the romances have associated symbolism that denotes the nature of the relationship between the initially unrecognised man and the woman who ultimately realises his true identity. Thus, Brangwine's recognition of Tristan's horse in 'The Book of Sir Tristram' as a means of identifying Tristan, recently recovered from his madness, reflects her relationship with the knight:

And so in the meane whyle cam a damesell that had sought Sir Trystram many wayes and dayes within thys londe. And whan she cam to the welle she loked uppon hym and had

31 Marie de France, 'Le Fresne', in Marie de France: Lais, ed. by Alfred Ewert (Oxford: Blackwell, 1960), pp. 35-48, 11. 413-19.

32 Marie de France, 11. 397-8.

33 'Le Fresne', 11. 413-19; 'Lay le Freine', in The Middle English Breton Lays, ed. by Anne Laskaya and Eve Salisbury, TEAMS Middle English Text Society (Kalamazoo: Medieval Institute Publications, 1995), pp. 61-87, 11. 371-72.

34 The mother's gloves and father's sword in Sir Degare function similarly: the clothing representing the maternal link, and the sword representing the paternal link. 
forgotyn hym as in remembraunce of Sir Trystrames, but by hys horse she knew hym, that hyght Passe-Brewell, that had ben hys hors many yerys. ${ }^{35}$

The horse, a symbol of Tristan's nobility and his knighthood, denotes a professional, non-intimate relationship between Tristan and Brangwine. This is the second time Brangwine recognises the transformed Tristan. She first identifies Tristan while he is still a wild man, his face and body transformed by his madness. Though she does not recognise him immediately, she notices that Isolde's brachet does recognise him (much like Argos recognises Odysseus in Homer's Odyssey), and thus concludes that the man must be Tristan. Hounds, too, are indicative of nobility. It is unusual in English romance that it is the lady's maid Brangwine rather than the hero's paramour herself who first makes the connection between the dog's behaviour and Tristan's identity. As Brangwine (and not Isolde) is the woman who recognises Tristan, the intimacy conferred by Tristan and Isolde's earlier ring exchange is absent in Malory's choice of horse and hound as revelatory objects in these scenes. Though Brangwine is willing to act as substitute for Isolde in King Mark's marriage bed, her emotional connection to Tristan is appropriately confined to an extension of her deep love and concern for Isolde, and in this recognition scene she is not presented as an amorous alternative to her lady. ${ }^{36}$

\section{The Role of Emotions}

Le Freine's mother swoons twice upon recognising the blanket and her daughter; Elaine, seeing Lancelot dressed as a fool and sleeping in her father's garden, 'felle in remembraunce of hym and knew hym veryly for Sir Launcelot. And therewythall she felle on wepynge so hartely that she sanke evyn to the erthe'. ${ }^{37}$ Displays of overwhelming emotion are present in many other romances' recognition moments as well, particularly fainting and weeping. In her research on medieval memory culture, Mary Carruthers has discussed the medieval belief of the importance of emotional accompaniment to memory retention and recall, pain as

35 Malory, p. 405.

36 The first reference to a dog recognising Tristan is in Gottfried von Strassburg's Tristan. In this version, the dog, Petitcrieu, is a fairy dog, and is given as a love-gift from Tristan to Isolde. It is possible that Malory does not recognise the Petitcrieu tradition or that he has altered it for greater realism. Malory, p. 395; Gottfried von Strassburg, Tristan, ed. by Reinhold Bechstein, 2 vols (Wiesbaden: Brockhaus, 1978), II, 11. 15769-16406.

37 Malory, p. 649. 
well as affection, sometimes referred to in medieval works on memory as 'passio' or 'affectio animi'. In Carruthers' words:

The word which Aristotle uses to classify the memorial phantasm is pathos, translated by William of Moerbeke as passio: the pathos is what a sense perception causes in the soul as a kind of image, the having of which we call a memory. Since it is a physical change or "affect," a phantasm is also an "affection" or passio. ${ }^{38}$

Thomas Aquinas, Francis of Assisi and Thomas of Celano all discuss the role of affect in memory recall; Carruthers summarises their points, saying, 'Affectus in this description is the agent by means of which rumination and memorization take place; in other words, remembering is an activity in which the emotions must be engaged in order for it to occur at all. ${ }^{39}$ It is appropriate, then, that almost without exception the disguised person is the woman's beloved, child or husband. In these recognition scenes, with or without the presence of recognition tokens, the hero appearing in front of his beloved and her nearly-wedded husband (always the romance's primary antagonist) is a test of her loyalty as much as it is a mechanism by which the hero can launch a dramatic surprise attack against those inside the castle. Her ability to recognise him despite his disguise is a testament to the strength of her affection for him. She is proven to have kept her love for him alive through his absence, as the strength of that emotion allows her to access memories of him so strong that they allow her to penetrate his altered appearance.

In the later thirteenth-century King Horn, Rimenhild gives Horn a ring 'for my luue pu hit were' with instructions to 'loke peran/ And penke vpon pi lemman' if he finds himself in need of courage. ${ }^{40}$ The author demonstrates the ring's effectiveness as a mnemonic token in a poignant moment in the battlefield, well before it is brought into play at the climactic moment of disguise revelation:

Pe sarazins he smatte

pat his blod hatte;

At evreche dunte

Pe heued of wente;

38 Mary Carruthers, The Book of Memory: A Study of Memory in Medieval Culture (Cambridge: Cambridge University Press, 2008), p. 85.

39 Carruthers, p. 217. For more information on medieval philosophy regarding the connection between memory and affection, see also Carruthers pp. 69, 75 and 87.

40 'King Horn', in King Horn, Floris and Blauncheflur, The Assumption of our Lady, ed. by J. Rawson Lumby and George H. McKnight (London: Oxford University Press, 1901), pp. 1-69, 1l, 603, 609-10. 


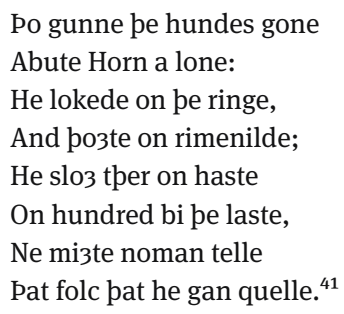

This tender moment of solitude and recollection that the author inserts in the midst of the heat and noise of battle establishes the ring as an object imbued with emotional significance private to Horn and Rimenhild. That the ring can trigger a memory of Rimenhild powerful enough to make the hero withdraw into private meditation in the middle of battle demonstrates the strength of Horn's love for her - similar to the reverie into which Lancelot falls when he sees the loose strands of Guinevere's hair in Chrétien de Troyes' Le Chevalier de la charrette. Thus when he returns to the kingdom in disguise and gives Rimenhild the ring by dropping it into her 'cuppe white', the scene becomes a test of Rimenhild's affections for Horn through her ability to recollect him..$^{42}$ The centrality of the ring as testing device of Rimenhild's emotional fidelity to Horn is made clear from the moment Horn enters the kingdom. A palmer he meets informs him that Rimenhild has married another, suggesting a breach in her faithfulness to Horn. However, this news is immediately undercut by the palmer informing Horn that

\author{
Ne mizte heo adrize \\ pat heo ne weop wip ize. \\ Heo sede pat ' heo nolde \\ Ben ispused wip golde. \\ Heo hadde on husbonde \\ Pe3 he were vt of londe. ${ }^{43}$
}

Rimenhild's specific refusal of a gold ring as a synecdoche of her unwillingness to marry King Mody strengthens the connection between Horn's ring and her emotional fidelity to him. Later, when Rimenhild first spies the ring, she is filled with 'dradde' - not that Horn might have come back to discover her marriage to King Mody - but that he might be 'isteue' (dead).$^{44}$ Her fidelity is finally proven when, overcome with grief at the sight of the ring, she

41 King Horn, 1l. 645-56.

42 King Horn, 1. 1212.

43 King Horn, 1l. 115-20, emphasis mine.

44 King Horn, ll. 1250, 1179 (in Laud and Harley MSS, 'ded'). 
[...] feol on hire bedde,

Per heo knif hudde,

To sle wip king lope

And hure selue bope. ${ }^{45}$

While she fails to recognise Horn in his palmer's guise, her recollection triggered by the sight of the token serves as proof of her emotional fidelity.

When these tokens are viewed as objects that carry emotional significance as well as memories of loved ones, objects that have a literary history in romance of reuniting separated loved ones, one can better understand Malory's insertion of an exchange of rings between Tristan and Isolde not found in the Prose Tristan, even if the rings never ultimately resurface as memory aids for disguise-recognition scenes. The placement of the exchange of rings and words between Tristan and Isolde fits the recognition-token narrative pattern found across most romances discussed in this essay: Isolde weeps (the display of strong emotion that aids memory imprinting), and just before exchanging rings they pledge their fidelity at the point of separation, when it seems likely that they will not see each other for seven years - time enough for the hero's appearance to drastically change, much like Horn and Rimenhild, or Isumbras and his wife. But the happy recognition-and-reunion modelled in King Horn and Isumbras is never fully realised in 'The Book of Sir Tristram'. Malory seems less interested in the ultimate proof of the lovers' fidelity through a final recognition scene than the concretisation of their love-bond through an initial performative promise. When Guinevere and Lancelot are discovered in Guinevere's tower, they similarly exchange rings and promises just before Lancelot flees. However, Tristan and Isolde's ring exchange, unlike Lancelot and Guinevere's, is complicated by Tristan's later failures to remain faithful to and remember Isolde. This emotional infidelity occurs on two occasions: when he marries Isolde Blanche-Mains and when he cuckolds Sir Segwarides. Malory moves Tristan's affair with Segwarides' wife from his source material to immediately follow his departure from Isolde. Dorsey Armstrong writes that Tristan 'provides an important commentary on Lancelot's career and affirmation of masculine knightly identity, as his relationship to his king, Mark and queen, Isolde, clearly stands as a dark reflection of Lancelot's own relationship to Arthur and Guenevere'. ${ }^{46}$ Isolde remains the faithful to Tristan during the interim between their initial parting and her wedding to King Mark, whereas Tristan's devotion to Isolde seems to be more enforced by the potion than inspired

45 King Horn, 11. 1281-84.

46 Dorsey Armstrong, Gender and the Chivalric Community in Malory's 'Morte d'Arthur' (Gainesville, FL: University Press of Florida, 2003), p. 25. 
by his own natural sentiments. Lancelot's devotion to Guinevere, by contrast, is never brought into question.

This frustration of the recognition-with-token narrative repeats one of the recurrent themes in Malory's works: that of proper action resulting in sorrow rather than an expected positive outcome. Consider, for example, Balin, who, being a man 'withoute velony other trechory and withoute treson', takes the adventure and achieves the sword, only to have this knightly achievement result in his and his brother's deaths. ${ }^{47}$ Percival's sister, devoted to Christian morality (unlike many courtly ladies, if Morgan le Fay's cup is to be believed) and to supporting the chivalric arena, dies in a bloodletting that, given the precedent Malory sets in the 'Tale of Balyn', the audience can expect to end happily, not tragically. ${ }^{48}$ Sir Urré is healed, a miracle that ends not in rejoicing but with the hero sobbing at the Grace granted him despite the morally corrupt state of the Round Table. Here, in the speech act and accompanying exchange of rings between Tristan and Isolde, Malory in effect sets up the audience for an ultimately positive reunion between the lovers, like those in the romances mentioned above. He then immediately disrupts the romance convention of fidelity despite prolonged separation, instilling the narrative with a sense of unease that is never quite resolved. He denies his audience the recognition-and-restoration ending traditional to earlier 'separation and restoration' romances, leaving the audience with a sense of loss and grief at what almost was, or what might have been.

\section{The Role of Gender}

Women's perceptive abilities are not exclusively dependent upon object-anchored memory. When Elaine, Pelles' daughter, recognises the mad fool Lancelot, she does so without the aid of a token; she 'felle in remembraunce of hym and knew hym veryly'. ${ }^{49}$ Outside the Arthurian English romances, Archistrata in Apollonius of Tyre recognises her husband after a fourteen-year absence while he fails to recognise her in her priestess' robes ('sche knew him wel, he hire noust'); Queen Candace, suspecting her visitor is not who he claims to be, recalls a metal engraving of Alexander and immediately discerns that the man before her is Alex-

47 Malory, p. 49.

48 Malory, pp. 65, 765-68.

49 Malory, p. 649. 
ander though he has traded places with one of his nobles. ${ }^{50}$ Women's authority as witness has biblical precedents, notably in the Passion, Burial and Resurrection. While men participate in the Passion and Burial, wetting Christ's lips with a wine-soaked sponge or carrying the body to the tomb, the women watch the proceedings, and when the tomb is discovered to be empty, it is the women who first see the risen Christ and who carry knowledge of his resurrection to the disciples. ${ }^{51}$

Women's limited mobility means that they are more likely to be confronted by a disguised person returning to the community than male characters are. The knight rides out of court, or the young heir is cast out in usurpation, and returns to his lands after many adventures; the woman remains behind, confined and surrounded by those who know her well. But to argue that more women are likely to recognise men than the reverse because it is more common for a man to be disguised than a woman is to fail to take into account the number of instances in which a man in a similar situation fails to recognise a person he knows well. As mentioned above, Apollonius, returning to his family, fails to recognise his wife, though she knows him immediately. Horn in Horn Childe cannot recognise his friend Wiard in his rags; the steward in Sir Orfeo is taken in by Orfeo's minstrel pose and wild appearance..$^{52}$ Throughout the English romances, men confronted with people in disguise are disproportionately depicted as less perceptive than

50 Though Candace has never met Alexander before, she has declared her love for him via letter before requesting that her metal smith make an image of him. Her amour lointain provides the necessary emotional connection to recall his graven image and allow accurate recognition. Kyng Alisaunder, ed. by G. V. Smithers, Early English Text Society (Oxford: Oxford University Press, 1952), 11. 6725-33, 7640-42. I have included the moment in Apollonius of Tyre in which Archistrata appears in front of her husband, Apollonius, as a priestess, and he fails to recognise her. However, due to the damage sustained to the manuscript, the text is ambiguous as to whether or not she is merely disguised as a priestess for her own safety after Denyse and Strangulion have orchestrated a coup, or if she has actually become a priestess after her ejection from her position as empress. 'Apollonius of Tyre', in Die alt-und mittelenglischen Apollonius-Bruchstücke, Studien und Texte zur englischen Philologie, ed. by J. Raith (Munich: Huber, 1956), 1. 36.

51 The New Oxford Annotated Bible, ed. by Michael D. Coogan (Oxford, New York: Oxford University Press, 2007), Matthew 27:55-56, 61; 28:1-9; Mark 15:40-41; 16:1-14; Luke 24:1-10; John 20:1-2, 10-18. The unknown Lollard author of Wycliffite Sermon 65, uncomfortable with Mary Magdalene's privilege of being the first to witness the risen Christ, wrote in the late fourteenth century: 'Pis gospel tellip hou Crist apperide to Mary Maudelen, for Crist wolde bat womman kynde hadde pis priuylegie bifore man bat he shewide hym aftir his dep rapere to womman pan to man, for wymmen ben freele as water and taken sunnere prynte of bileue.' ('Sermon 65', in English Wycliffite Sermons, ed. by Anne Hudson, 5 vols (Oxford: Clarendon, 1990), III, p. 199).

52 Horn Childe and Maiden Rimnild, ed. by Maldwyn Mills, (Heidelberg: Winter, 1988), 1. 876; 'Sir Orfeo', Codex Ashmole 61: A Compilation of Popular Middle English Verse, ed. by George Shuffleton (Kalamazoo, MI: Medieval Institute Publications, 2008), 11. 498-553. 
women. Amis and Amiloun provides another such example, and is perhaps the best confirmation of the medieval English gender bias of perception insofar as the text follows perfectly the pattern of romances that incorporate token-based recognition scenes in every respect except that the separated pair is same-sex and the ultimate recognition scene fails. In this revelation narrative, Amis gives Amiloun one of a matching set of golden cups at their departure, and the object features prominently in their reunion. The emotional performances of Amis and Amiloun are similar to those of the women in the aforementioned romances: they weep and swoon at their initial separation, and Amis weeps and swoons again at their reunion. These elements - the narrative pattern, the token motif, the emotional performances - parallel those found in the majority of female-male disguised reunions discussed in the texts above. However, there is a key difference: even when presented with the cup, Amis does not successfully recognise the now leprous beggar Amiloun. Even at his wife's suggestion that the man before him is Amiloun, Amis refuses to entertain the possibility that it is his long-lost friend. Amiloun's devoted nephew Amoraunt must declare his uncle's identity to Amis. Men in Le Morte Darthur use objects as tokens of remembrance, but these tokens are to remember the deceased, and not to identify people. Joseph, making a cross upon a white shield with his own blood, tells Evalake: 'Now may ye se a remembraunce that I love you, for ye shall never se thys shylde but ye shall thynke one me'. ${ }^{53}$ The 'cote male tayle' functions similarly: as a remembrance of Sir Brewnor's father and his treacherous death. ${ }^{54}$ Women, on the other hand, in Malory and throughout several English romances, use objects in a similar fashion (for example, Eve burying the apple branch in the 'Tale of the Sankgreal'), but also use them for identification. ${ }^{55}$ Malory generally embraces the expectation within the genre and in medieval English society that women would be better at both recognition and object-anchored memory; Elaine, Isolde's mother and Brangwine recognise men when their fathers, husbands, or other members of the court do not. Isolde remains devoted to Tristan while Tristan forgets her, first cuckolding Segwarides and later marrying Isolde Blanche-Mains. Molly Martin has argued for the gaze in the Morte Darthur as feminine in its passivity; thus if men are caught gazing, they must reconfirm their masculinity through action. Malory's approach to recognition scenes, and particularly object-triggered recognition

53 Malory, p. 681.

54 Malory, p. 360.

55 Malory, p. 757. 
scenes, correlates with Martin's view: sympathetic female characters are placed in positions whereby they are the perceivers, the heroic men the perceived. ${ }^{56}$

\section{Failed Recognition}

The few narratives in which the woman fails to recognise a person in disguise, far from undermining this pattern of presenting women as social memory keepers or more perceptive than men, in fact strengthen it. Igraine in Arthurian romances and the Duchess of Austria in Sir Gowther are both raped by individuals disguised as their respective husbands and fail to detect the disguise until their rapists reveal themselves. However, these are supernatural disguises: Merlin enchants King Uther to look like Igraine's husband, and in Sir Gowther a devil takes on the duke's form. ${ }^{57}$ The authors use the supernatural aspect of the disguises to excuse the women from not fulfilling their duty of familial recognition properly - or else to leave their degree of culpability deliberately ambiguous. Margaret Robson and Raluca Radulescu have discussed in depth the ambiguity surrounding the Duchess of Austria's failure to recognise a devil in disguise in Sir Gowther. They note that her prayer 'to God and Maré mylde/ Schuld gyffe hur grace to have a chyld,/ On what maner scho ne roghth' suggests a willingness to turn a blind eye to the devil's true identity. ${ }^{58}$

Malory achieves Igraine's exoneration largely through silence: during Uther's infiltration of the castle and rape of Igraine, the audience is not privy to Igraine's point of view. Her thoughts are only introduced after Uther has left and she is told of the death of her husband. She 'merveilled who that myghte be that laye with her in lykenes of her lord. So she mourned pryvely and held hir pees' ${ }^{59}$ Her reactions - first marvelling, then mourning - establish her blamelessness. The encounter, therefore, becomes as much a testament to Igraine's fidelity to Gorlois as to the power of Merlin's magic: he can disguise a man so well that a woman

56 Molly Martin, Vision and Gender in Malory's Morte Darthur (Cambridge: D. S. Brewer, 2010), pp. 5, 15, 176.

57 Malory, pp. 3-4, retained from 'L’Estoire du Merlin', p. 67; 'Sir Gowther', in The Middle English Breton Lays, ed. by Anne Laskaya and Eve Salisbury, TEAMS Middle English Text Series (Kalamazoo, Michigan: Medieval Institute Publications, 1995), pp. 263-307, 11, 66-81.

58 Sir Gowther, 1l. 64-66; Margaret Robson, 'Animal Magic: Moral Regeneration in Sir Gowther', in Yearbook of English Studies, 22 (1992), 140-53 (pp. 141-43); Raluca Radulescu, 'Pious Middle English Romances Turned Political: Reading Sir Isumbras, Sir Gowther, and Robert of Sicily in Fifteenth-Century England', Viator, 41.2 (2010), 333-59 (p. 351).

59 Malory, p. 4 
cannot distinguish him from her own husband. The narrative's delay of the truth test that generally accompanies a disguise encounter further consolidates her blamelessness, as she is reluctant to tell Uther, now her husband, of the child's paternity. If she had suspected Uther she would have been more willing to divulge the puzzling circumstances of Arthur's conception. Furthermore, the emotional force of her reaction ('the quene made grete joye') following Uther's revelation that he is, in fact 'the fader of her child' proves her integrity. ${ }^{60}$

The paucity of women's failed recognition scenes in English romance makes Isolde's failure to recognise Tristan during his period of madness striking in its rarity. She has neither enchantment nor devilry to excuse her. The disruption of the reunion motif between lovers enlivens the narrative. It is not uncommon for medieval authors, particularly later authors, to disrupt common motifs to retain audience interest. ${ }^{61}$ The gendered aspect of the recognition trope is upheld as Brangwine recognises the hero (as discussed above), but like many of Tristan's interactions with the opposite sex in the Morte Darthur, she is the wrong woman. Again in this scene as with other moments of failed recollection in 'The Book of Sir Tristram', the audience is presented with an achingly near miss: 'whan the quene loked uppon Sir Trystramys she was nat remembird of hym, but ever she/ seyde unto Dame Brangwayne, "Mesemys I shulde have sene thys man here before in many placis.”"62. Like Igraine, Isolde's emotional display following the revelation of Tristan's identity (she 'felle downe in a sowne and so lay a grete whyle') erases any doubt of her devotion to him. ${ }^{63}$

Here, as elsewhere in the Morte Darthur, love does not conquer all, but Malory mixes bitter and sweet: 'as sone as Sir Trystramys sye her he knew her well inowe, and than he turned away hys vysage and wepte'. ${ }^{64}$ This is not a moment of masculine perspicacity but rather a moment of healing. Reunion with Isolde heals Tristan's mind, echoing their first meeting when Isolde healed him of his wound. It is a scene that simultaneously looks backward as it looks forward, con-

60 Malory, p. 5.

61 Helen Cooper discusses medieval romance authors' frustration of a number of other motifs, such as magic that fails, in The English Romance in Time: Transforming Motifs from Geoffrey of Monmouth to the Death of Shakespeare (Oxford: Oxford University Press, 2004), pp. 137-72, esp. pp. $144-51$.

62 Malory, pp. 394-95.

63 Malory, p. 395.

64 Malory, p. 395. 
firming their love for each other as it alludes to the day when Isolde cannot heal her beloved. ${ }^{65}$

In conclusion, these disguise-recognition narratives suggest a gendered view of perceptiveness relating to identity. Women are consistently depicted as more skilled at identity perception than men. This is supported by historical evidence of women occupying legal and social roles as memory-keepers of identities. The commonality of the token of recognition motif and emotional performance, when viewed in light of contemporary concepts of memory retention, implies that these moments of disguise revelation are primarily acts of recollection, stimulated by emotion. These motifs suggest that it is perhaps social belief that women's emotional intensity facilitates better memory retention, and thus identification. Or, perhaps these narratives illustrate the self-perpetuating notion that women are more perceptive than men, because women were expected and trained to take on the emotional labour of social perception. Malory incorporates these gendered disguise-recognition motifs to signal to the audience the nature of the relationship between individuals (as in the recognition scenes between Tristan and Isolde's mother and later between Tristan and Brangwine, or the promise of emotional fidelity between Tristan and Isolde) and to set up audience expectation for a reunion narrative (as in the ring exchange between Tristan and Isolde), thus casting an early shadow over Tristan and Isolde's relationship and increasing the sense of tragedy later in the narrative when such expectations are not met.

65 In the Prose Tristan, Tristan sends a ring to Isolde, who through Isolde Blanche-Mains' jealousy, does not receive it in time to save him. Like Lamorak's death, Malory keeps Tristan and Isolde's deaths 'off stage'. These off-stage tragedies save the emotional punch of 'on stage' deaths for the implosion of the Round Table in the final book. 